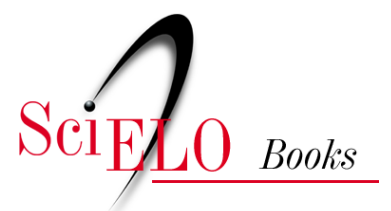

\title{
I. A chegada da família real e as mudanças sociopolíticas
}

\author{
Juliana Gesuelli Meirelles
}

\section{SciELO Books / SciELO Livros / SciELO Libros}

MEIRELLES, J.G. A chegada da família real e as mudanças sociopolíticas. In: A família real no Brasil: política e cotidiano (1808-1821) [online]. São Bernardo do Campo: Editora UFABC, 2015, pp. 9-34. ISBN: 978-85-68576-96-0. https://doi.org/10.7476/9788568576960.0002.

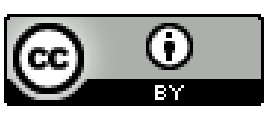

All the contents of this work, except where otherwise noted, is licensed under a Creative Commons Attribution 4.0 International license.

Todo o conteúdo deste trabalho, exceto quando houver ressalva, é publicado sob a licença Creative Commons Atribição $\underline{4.0}$.

Todo el contenido de esta obra, excepto donde se indique lo contrario, está bajo licencia de la licencia $\underline{\text { Creative Commons }}$ Reconocimento 4.0. 
A CHEGADA DA FAMÍLIA REAL E AS MUDANÇAS SOCIOPOLÍTICAS

No dia 14 de janeiro de 1808, o brigue Voador trazia ao porto do Rio de Janeiro a notícia de que a Família Real estava a caminho do Brasil. Desde então, os ânimos da sociedade carioca fervilhavam. Três dias depois, em 17 de janeiro, o desembarque das sete naus portuguesas e dos três barcos ingleses no cais do porto despertava a imensa curiosidade da população que aguardava ansiosamente a chegada do Príncipe Regente e sua corte em terras americanas. Para desapontamento da maioria da casta real, entretanto, chegavam apenas as duas irmãs da rainha D. Maria I: d. Maria Benedita e D. Maria Ana, além das duas infantas, Maria Francisca de Assis e Isabel Maria.

Sem saber o que havia acontecido com os demais membros da dinastia de Bragança, as nobres senhoras e senhoritas da família real não aceitaram o convite do conde dos Arcos para aportarem em terra firme. Preferiram ficar a bordo dos navios à espera de notícias, que só chegariam ao Rio um mês depois. Enquanto isso, os demais tripulantes circulavam pela cidade em busca de acomodação.

Esse momento, ainda tão singelo perto do que viria a ser o dia 7 de março, já prenunciava as importantes transformações que ocorreriam na sociedade luso-brasileira. Novas etiquetas, rituais e solenidades começavam a ser vivenciados pelas ruas da sede da Colônia que, em 22 de fevereiro, ficava ciente de que a Família Real - juntamente com a nobre comitiva portuguesa - encontrava-se em Salvador e, tão logo fosse possível, estariam no Rio de Janeiro. A tônica das conversas girava em torno da chegada em carne e osso da Rainha, do Príncipe Regente, seus familiares e acompanhantes. Todos se preparavam para a pompa que enfeitaria a grande ocasião...

Enfim, em 7 de março, a esquadra real aportava no porto da baía de Guanabara. A cidade estava em festa e o espetáculo da chegada foi um momento único: as salvas de canhões, os tiros de fuzis e as badaladas dos sinos das igrejas anunciavam a entrada triunfal da família real que recebia as homenagens por toda a parte. D. Maria, dom João e Carlota Joaquina foram recepcionados pela elite política da cidade, composta, sobretudo, pelo Conde dos Arcos, os membros do Senado da Câmara, além de renomados eclesiásticos, civis e militares. Com olhares curiosos, o restante da população se amontoava pelas praias e morros assistindo atentamente ao entourage, que ganharia contornos mais efusivos no dia seguinte. Em suas memórias, 
o padre Luiz Gonçalves dos Santos, mais conhecido como padre Perereca, registrava sua emoção ao ver a entrada da realeza na América Portuguesa.

Rio de Janeiro, Cidade a mais ditosa do Novo Mundo! Rio de Janeiro, ai tens a tua Augusta Rainha e o teu excelso Príncipe com a sua Real Família, as Primeiras Majestades que o Hemisfério Austral viu e conheceu. Estes são os teus soberanos e senhores, Descendentes e Herdeiros daqueles Grandes Reis que te descobriram, te povoaram, te engrandeceram ao ponto de serem de hoje em diante Princesa de América e Corte dos Senhores Reis de Portugal; enche-te de júbilo, salta de prazer, orna-te dos teus mais ricos vestidos. Sai ao encontro dos teus Soberanos e recolhe com todo o respeito, veneração e amor o Príncipe ditoso, que vem em nome do Senhor visitar o seu Povo. (Santos, 1825: 16)

Apesar da chegada triunfal, os membros da realeza só desembarcariam efetivamente em solo carioca no dia seguinte, em 8 de março, por volta das quatro horas da tarde. Os júbilos de apreço popular pela presença das personalidades reais se faziam sentir nas diversas manifestações. Foguetes, salvas de artilharia e repiques de sinos em meio às chuvas de folhas e flores atenuavam temporariamente as angústias do príncipe regente por ter deixado o Reino invadido à mercê dos franceses.

Enquanto dom João se deixava inebriar pelas congratulações de boas vindas e pela belíssima geografia da Baia de Guanabara, D. Carlota Joaquina chorava convulsivamente: tinha seu orgulho ferido por ter que aceitar a condição - para ela degradante - de ser uma princesa e futura rainha de possessões coloniais.

O amor de dom João e o repúdio D. Carlota pelo Brasil foi uma diferença central nos olhares e sentimentos que cada um cultivou pelo país ao longo dos treze anos de permanência nos trópicos. Se essa percepção já se fazia presente logo nos instantes iniciais da chegada da corte, também foi no primeiro contato da realeza com seus súditos da Colônia que os rituais cortesões se manifestavam de modo a marcar a singularidade dos novos tempos e costumes. "Uma extensa parada militar tomava a praça e formava alas para a Rua do Rosário e Rua Direita até ao adro da Catedral. O cortejo progredia com lenta, imponente majestade", expõe Luiz Norton (1938: 52).

Já na Catedral, a missa que os recepcionava enchia de pompa a cidade. Com grande instrumental, os súditos mais ilustres cantavam entre outras músicas o hino de Graça, ao mesmo tempo em que suas altezas concediam um beija-mão geral, um ritual público da realeza que teve importância central nas relações sociopolíticas entre o soberano e seus súditos no período joanino. "Era uma cerimônia que punha o monarca em contato direto com o vassalo, que lhe apresentava as devidas vênias e suplicava por alguma mercê. 
Reforçava-se nele a autoridade paternal do soberano protetor da nação", relata Jurandir Malerba (2000: 184). Finda a recepção, a realeza seguia em coches próprios para o Palácio, sempre acompanhados da multidão curiosa para saber o que aconteceria dali em diante.

Se a beleza do cenário geográfico da cidade encantava a maioria da corte portuguesa que desembarcava no porto do Rio, os primeiros dias mostrariam a precariedade da estrutura da nova capital. "Numa pequena área espremida entre a praia e a montanha, formada por escassas ruas paralelas e mais algumas transversais, rodeadas por matas e logradouros desertos, mais de dez mil pessoas foram alojadas às pressas, com a chegada da Família Real, transformando a pequena cidade dos vice-reis em capital do império português na América", descreve a historiadora Leila Mezan Algranti (1988: 26).

Para acomodar os acompanhantes da corte, o conde dos Arcos instituiu o sistema de aposentadorias que, na prática, requisitava as casas dos moradores locais para aconchego da nobreza. Na porta de muitas casas foram pregadas as letras $P R$ - Príncipe Regente -, interpretadas pela população como Ponha-se na Rua. "O afluxo de uma grande quantidade de pessoas agravou os problemas urbanos. Além da falta de moradia, havia carência no abastecimento de água, saneamento, segurança pública", descreve o historiador Paulo de Assunção (2008: 88). Essa situação causou um enorme rebuliço tanto para a população que ficava desabrigada, quanto para a nobreza portuguesa que considerava as moradias desconfortáveis, mal construídas e sem o luxo das suas residências em Lisboa. Já a população mais pobre ficou marginalizada à região norte da cidade, circunscritas aos bairros de Catumbi e Mata-Porcos. Nesse espaço, as habitações se restringiam a choças aglomeradas entre os morros e o mar, o que já marcava a profunda desigualdade social no especo geográfico (Lima, 2000: 106).

Aos poucos, no entanto, as transformações urbanas foram modificando a estrutura da cidade. Para além das quatro freguesias já existentes - Sé, Santa Rita, São José e Candelária -, foi criada o Engenho Velho. Novas ruas foram pavimentas e as estradas alargadas. A iluminação, saneamento, abastecimento de água potável e, consequentemente, a higiene também foram aspectos que sofreram importantes melhorias na cidade. Ou seja, entre os anos de 1808 e 1822, a área do Rio de Janeiro havia triplicado. Mas como bem adverte a antropóloga Lilia Schwarcz, "Se a vila se modificou para se vestir como capital do império português, as permanências são evidentes. Suas casas e traçados coloniais, suas festas tomadas por costumes africanos, seus hábitos alimentares orientais... nada permite duvidar de um universo obrigatoriamente plural" (Schwarcz, 2008: 6). A pluralidade de universos 
se fez sentir nos mínimos detalhes. A rotina da vida no Rio de Janeiro se transformava por completo.

A começar pelo crescente número de habitantes entre os anos de 1808 e 1821. Se até 1808 o Rio de Janeiro era uma cidade com cerca de 60.000 habitantes, o censo de 1821 já apontava para uma população em torno de 79.321 pessoas, contando o alto número de estrangeiros que fixaram residência (em torno de 10.000 mil pessoas), escravos, libertos e população livre (Martins, 2008: 107).

Esse aumento populacional está intimamente relacionado às alterações socioeconômicas advindas da transferência da Família Real para o Brasil. Porém, se desde o final do século XVIII, a importância do Rio como centro importador de escravos já era notável, nos treze anos em que a Corte permaneceu no Brasil houve a predominância da capital no cenário internacional, sobretudo devido à abertura dos portos e o processo de transição de uma economia fechada e monopolista para uma economia aberta. O porto do Rio de Janeiro se tornava o principal centro econômico do país.

$\mathrm{O}$ crescimento da cidade provocou uma ampliação significativa na demanda de serviços urbanos, o que refletia diretamente na valorização do tráfico negreiro. "A crescente necessidade de mão de obra fazia com que os olhos se voltassem para a África. Após 1809, o volume de tráfico de escravos para o Rio de Janeiro aumentou sensivelmente", complementa Algranti (1888: 33). Por volta da década de 1820, a cidade chegou a ter 34 mil escravos por ano, uma estatística bem acima daquela vigente em 1809, que apontava uma entrada anual do número de negros na cidade entre $5.839 \mathrm{e}$ 10.536 (Klein, 1978: 54-55).

População total da cidade do Rio de Janeiro em 1808 e 1821

\begin{tabular}{|c|c|c|c|c|c|}
\hline Ano & Fogos & $\begin{array}{c}\text { População } \\
\text { Livre }\end{array}$ & Libertos & Escravos & Total \\
\hline 1808 & 4.000 & 47.090 & 1000 & 12.000 & 60.000 \\
\hline 1821 & 10.151 & 43.139 & -- & 36.182 & 79.321 \\
\hline
\end{tabular}

(Fontes: 1808: Luccock. Notas sobre o Rio de Janeiro e partes meridionais do Brasil. Belo Horizonte, 1975, p. 28. 1821. Censo de 1821. RIHGB, t.33, parte.1, 1870, p. 135-142)

A nova estrutura da cidade despertava os holofotes, senão do mundo, pelo menos dos europeus, ávidos por receberem as notícias da Corte portuguesa e conhecerem as transformações implementadas pelo Príncipe Regente dom João na nova capital do Império. Viajantes, cientistas, 
estrangeiros de toda parte chegavam ao Rio de Janeiro senão com o objetivo de fixar moradia, pelo menos de explorar as faces ainda desconhecidas da América Portuguesa. Tal foi a transformação que, em 9 de junho de 1811, foi publicado um edital da Intendência da polícia que já enunciava claramente a posição adquirida pela cidade como capital do Império Português, agora com sede nos trópicos.

(...) Havendo se elevado esta cidade a alta hierarquia de ser hoje Corte do Brasil (...) não pode nem deve continuar a conservar (...) antigos costumes que apenas podiam tolerar-se, quando era reputada com uma Colônia e que desde muito tempo não sofrem em povoações cultas e de perfeita civilização (...) testemunhos da antiga Condição de Conquista e Colônia, concorrendo para estabelecer a sua Corte e fazê-la mais notável aos olhos das Nações Estrangeiras. (ANRJ - CÓD.323, v.1. fl. 88-88v.)

Como bem explicitava Paulo Fernandes Viana, intendente da polícia, desde 1808 que os novos rituais ditos civilizados passaram a fazer parte do cotidiano da cidade. O calendário oficial imposto pela realeza colocava em cena datas comemorativas que se intercambiavam entre os dias santos da religião católica e os fatos políticos da monarquia. Celebrações religiosas, cortejos e aniversários reais, paradas militares. Enfim, uma ampla gama de solenidades públicas passou a ocorrer quase todo mês. Cada festejo, contudo, tinha uma finalidade específica. "Determinados eventos eram lembrados com uma missa cantada; outros eram assinalados pelo "beija-mão" no Paço e havia as grandes comemorações que articulavam uma série de eventos festivos, como as Aclamações reais", explica o historiador Emílio Lopes (2004: 30). Apesar das diferenças, todas as comemorações tinham como eixo a presença da Família Real, fosse de corpo presente ou por meio de retratos. "Era fundamental que os signos e sentidos da realeza circulassem pelo tecido social, fossem comunicados e, de alguma forma, apreendidos", elucida a historiadora Iara Lis C. Schiavinatto (1999: 53).

Durante as mais diversas festividades, era valorizada a fé dos indivíduos que vivenciavam nesses momentos formas diferenciadas de aprofundamento do espaço destinado à interlocução social e ao debate político. Nas comemorações que exteriorizavam as práticas monárquicas, os projetos políticos da realeza se faziam notar com mais intensidade: a aura paternal e amorosa do Rei para com os seus súditos era exaltada, numa clara tentativa de minimizar as faces da crise vigente no Antigo Regime Português. "A cidade era o local onde se desenrolavam as grandes cenas da vida cotidiana de seus habitantes, mas também era o espaço de representação do poder", afirma Paulo de Assunção (2008: 96). 


\section{A reestruturação administrativa da Corte}

Desde 1808, as medidas reais já apontavam para uma mudança de cenário na Corte. A manutenção e o bom funcionamento da burocracia estatal da monarquia portuguesa deste lado do Atlântico pressupunham a transladação de importantes instituições régias cuja lógica, segundo a historiadora Leila Algranti, "inseria-se na antiga política colonial de fortalecer no Brasil um Estado extremamente dependente, vinculado às organizações de Lisboa, sem autonomia ou criatividades próprias" (1988: 35). Apesar disso, as instituições régias aqui instituídas alterariam significativamente a prática das decisões políticas no Império Português e também a vida cotidiana da cidade.

A Intendência-Geral de Polícia da Corte, uma das principais instituições que garantiam a segurança pública, foi criada em 5 de abril de 1808. Com amplos poderes, o desembargador carioca Paulo Fernandes Viana assumiu o cargo de intendente, ocupando-o até fevereiro de 1821. Responsável pela guarda pessoal da família real, também tinha como atribuições fiscalizar a construção dos teatros, manter a "ordem" das festas públicas, deter escravos fugidos, prender pessoas "perigosas" ao governo, vigiar a cidade para que não houvesse badernas ou crimes, registrar a entrada e saída de estrangeiros, assim como cuidar da reestruturação da cidade, que crescia e se transformava a olhos vistos.

Houve momentos, no entanto, que a sua autoridade foi publicamente contestada. Em 1811, ao prender pessoas consideradas inocentes pelo Príncipe Regente, Viana recebeu um comunicado na seção noticiosa da Gazeta do Rio de Janeiro que ordenava a soltura dos presos. ${ }^{1} \mathrm{O}$ aviso foi assinado por D. Rodrigo de Souza Coutinho, Conde de Linhares, ninguém menos que o ministro de maior proeminência no governo até 1812.

Com a transladação da Família Real para o Brasil, D. Rodrigo ficou responsável pelo Ministério dos Negócios Estrangeiros e da Guerra, órgão de suma importância política na estruturação administrativa do Império deste lado do Atlântico. Entre os anos de 1808 e 1812, o ministro foi febril na tentativa de implantação de atividades reformadoras a fim de consolidar o seu projeto político de um novo império, que fosse capaz de evitar as explosões revolucionárias no Brasil. Ao defender tenazmente a aliança com

\footnotetext{
1 Para uma análise mais detalhada sobre a Gazeta do Rio de Janeiro ver: MEIRELLES, Juliana Gesuelli, Imprensa e poder na corte joanina: A Gazeta do Rio de Janeiro. Ed. Arquivo Nacional: Rio de Janeiro, 2008; CARDOSO, Tereza Maria Rolo Fachada Levy. A Gazeta do Rio de janeiro: subsídios para uma história da cidade (1808-1821), Dissertação de Mestrado, UFRJ, RJ, 1988 e SILVA, Maria Beatriz Nizza da, Gazeta do Rio de Janeiro (1808-1822): Cultura e Sociedade: Rio de Janeiro: Eduerj, 2007.
} 
os ingleses, acreditava primar pela alta consideração de Portugal entre as nações europeias o que, para ele, garantiria também a unidade do vasto império colonial, já abalada pelos ventos das novas ideias revolucionárias. "Construir uma unidade nacional luso-brasileira era a ideia central da nova política proposta pelo ministro, demonstrando o quanto o governo ilustrado estava atento às questões cruciais daquele momento vivido", explicita a historiadora Maria de Lourdes Viana Lyra (1994: 72).

Sua morte súbita, em janeiro de 1812, gerou uma onda de boatos pela cidade do Rio de Janeiro. Ainda segundo Lyra, esta situação bem demonstrava "o clima de tensão gerada entre os distintos grupos envolvidos diretamente no processo de implementação do projeto de um novo império lusitano com sede no Brasil" (Lyra, 1994: 145), cujas divergências políticas giravam em torno da defesa de ideais antagônicos: os interesses nacionais, entre portugueses que defendiam os interesses do Reino e a parte de um grupo ilustrado, que defendia a preeminência do Brasil no cenário nacional. Tal foi a importância de D. Rodrigo que, em 29 de janeiro de 1812, era publicada uma pequena biografia do ministro nas páginas da gazeta oficial. A retórica laudatória do redator o considerava uma das figuras mais importantes do governo, "um dos mais firmes esteios da monarquia portuguesa" que muito contribuíra para "o aumento e prosperidade da Nação". 
Aviso so Jutendense Geral dis Policia.

Havenda subido à Augusta Presença de S. A. R, - Priscipe Regente Nosso Sexhon a Conta, e Processos Inquisitorios, que V.S. me remettêo em dita de 27 de Setembro, das Pessoass que fôtạa acçcusadas, como suspeitas, e vendo S. A. R. que a accusaçáo náo procede, , antes sq mostra pelos exames 2 que se procedeo, que rodas as Pessons accusadas e detidas náo só estéo innocentes, mas derio em toda a parte decididas provas da spa fidelidade e amor para o seu Soberano, o Melhor dos Principes: He - Mesmo Augusto Senhor Servido que V. S. náo só mande pôr .em libendade os que estáo aqui detidos, mas que, tambem mande praticat o mesmo com hum dos Navarros, que ficou ainda na Babia, e thes déchaie, que $S_{i} A . R$. ficou inteiramente convencido da sua innocencia ; e que ao Pio e Virtuoso Coraḉo de hum táo Benigno Soberano, foi bem doloroso, que, a necessidade, as criticas circumstuncias imperiosas do mopento, e puma denuncia, que parecia fundada, thes exusassem huma desagradavel detençáo, de que com tudo thes náo deve resuitar maior ineommodo, logo que fica justificada a sua innocencia, e restitcuidos a Graça do seu Soberano. O mesmo Ordena S. A.R., que V.S. pratique a respeito do Fespanbol Harrecbe, pondo-o em inteira liberdade, dendo-lhe Passaporte para poder seguir a sua viagem para a Babia e Havanna, depois de se the rescituir tudo o que the foi aprehendido.

\section{Deos guarde a V.S. Palacio do Rio de fanciro} em 28 de Setembro de 1811 .

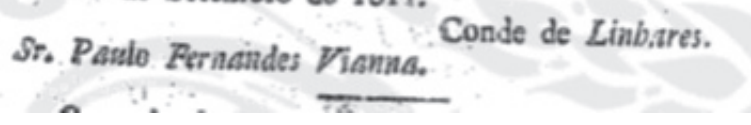

(Fonte: Gazeta do Rio de Janeiro, 9 de Novembro de 1811, n.81, p.2)

Apesar das controvérsias políticas no âmbito imperial, a preponderância do intendente da polícia - no aspecto local - fazia-se presente em múltiplos aspectos no governo joanino: das diversas ocorrências da vida cotidiana às decisões referentes à política imigratória, Viana mantinha um canal de comunicação direta com D. João, que o encontrava três vezes por semana a fim de ter ciência de tudo o que se passava na cidade. A maioria das pessoas o considerava uma autoridade terrível, já que a sua figura repressora tinha o aval e a confiança do monarca. ${ }^{2}$ Ao deixar o cargo de intendente em 1821,

2 BNRJ. MORÃES, Alexandre José de Melo, Dados sobre a chegada ao Rio de Janeiro 
Viana se vangloriava de seus feitos, ressaltando os benefícios que trouxera para o processo de urbanização do Rio.

"Aterrei imensos pântanos da cidade com que se tornou mais sadia (...), fiz calçada na rua do Sabão e de S. Pedro, na Cidade Nova: na R. dos Inválidos (...) fiz o cais do Valongo (...) Por não haver na cidade abundância d’água para o uso público consegui (...) conduzir água até para beber em uma légua de distância... 'criei' e fui sempre aumentando a iluminação da cidade" (Viana, 1892: 374-375.)

Um mês depois da criação da Intendência da Polícia - que marcava sua centralidade dentre as instituições diretamente relacionadas à vida cotidiana -, dom João implantava a primeira tipografia na Colônia, denominada de Impressão Régia. O decreto que oficializava a publicação de papéis públicos e particulares, em 13 de maio de 1808, era produzido nos moldes retóricos do Antigo Regime português:

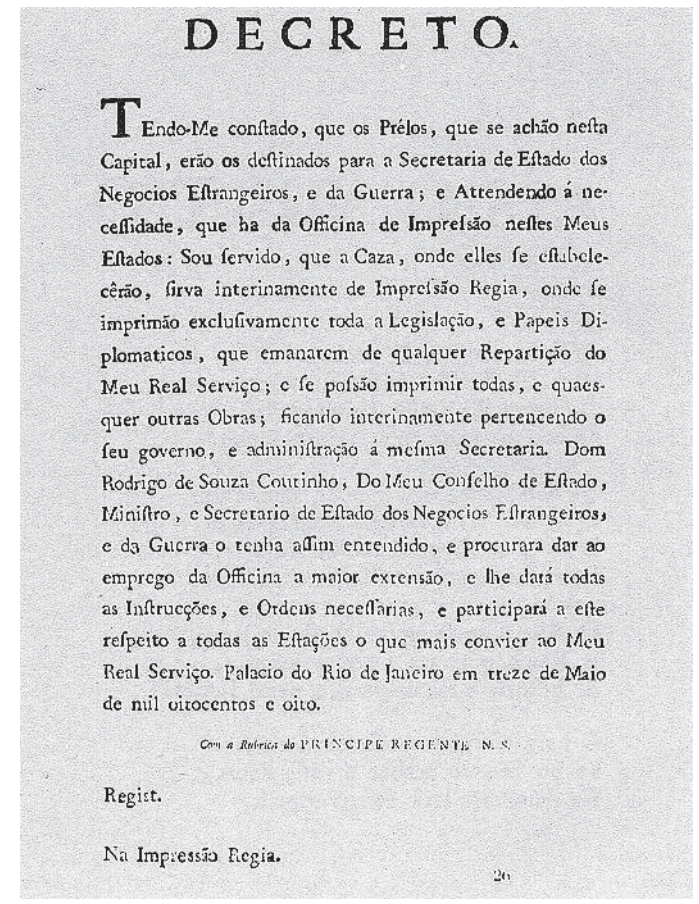

da Família Real, problemas de habitação para a comitiva, vida social e política, hábitos da familia real, volta para Portugal, falecimento de D, João VI e Pedro I como imperador, S.l, s.d, Original (transcrição feita por Cecília Coelho, maio de 2001). Divisão de Manuscritos, II-30, 23, 6,7. 
A data que institucionalizava o nascimento da palavra impressa no Brasil não foi, de forma alguma, uma escolha aleatória; ao contrário, o decreto era publicado exatamente no dia do aniversário de dom João, um dia muito significativo no calendário da realeza. Marcar as medidas estatais nas datas natalícias da família real também fazia parte da política absolutista, pois o "controle do tempo era fundamental para perpetuar uma memória das ações do Rei e dar legitimidade ao seu poder", afirma o historiador Emílio Lopes (2004: 89).

Em 24 de junho de 1808, pouco mais de um mês depois da publicação do decreto real de 13 de maio, era divulgado um regimento que delimitava ainda mais as funções da junta administrativa da Impressão Régia e do intendente da polícia Paulo Fernandes Viana diante da produção e circulação de papéis públicos e privados. Dizia o documento que competia aos diretores da tipografia "examinar os papéis e livros que se mandassem publicar e fiscalizar para que nada se imprimisse contra a religião, a moral e os bons costumes", tendo o intendente da polícia total autorização para prender aqueles que transgredissem a "segurança pública", ao veicularem escritos impressos ou manuscritos que fossem considerados sediciosos pelos censores da realeza, sobretudo aqueles cujas ideias fossem contrárias ao governo. Quem ousasse ultrapassar esse limite estava sujeito a pagar uma multa de duzentos mil réis, que poderia ser cobrada mesmo que o acusado não estivesse ciente da acusação, já que a polícia admitia e incentivava denúncias em segredo.

Peça-chave no processo de comunicação interatlântica, intimamente associado à veiculação da propaganda do Estado e, consequentemente, à sustentação do Império Português nos dois lados do Atlântico, a Impressão Regia tinha numerosas funções que extrapolavam a impressão exclusiva de todos os papéis ministeriais e diplomáticos do serviço real de todas as repartições. Ficava sob a sua responsabilidade também imprimir as obras de particulares, tanto quanto produzir e fazer circular a Gazeta do Rio de Janeiro. ${ }^{3}$ Mesmo sob constante atuação da censura, como editora a Impressão Régia publicou até 1822 muitos livros de amplo valor cultural. Nesse período, foram impressos 720 títulos que versavam sobre diversas temáticas: opúsculos, sermões, prospectos, obras literárias e científicas

3 Sobre a importância da Gazeta do Rio de Janeiro, ver: CAMARGO, Ana Maria de Almeida e MORAES, Rubens Borba de, Bibliografia da Impressão Régia do Rio de Janeiro, Edusp, São Paulo, 1993. MEIRELLES, Juliana Gesuelli, Imprensa e poder na corte joanina: A Gazeta do Rio de Janeiro.Ed. Arquivo Nacional: Rio de Janeiro, 2008. CARDOSO, Tereza Maria Rolo Fachada Levy, A Gazeta do Rio de janeiro: subsidios para uma história da cidade (1808-1821), Dissertação de Mestrado, UFRJ, RJ, 1988 e SILVA, Maria Beatriz Nizza da, Gazeta do Rio de Janeiro (1808-1822): Cultura e Sociedade: Rio de Janeiro: Eduerj, 2007. 
sobre matemática, história, ciência política, economia e filosofia, teatro, romances, dramas, entre outros. Já em relação à documentação oficial, no mesmo período foram contabilizadas 1.427 publicações (Schwarcz, 2002: 251).

Os censores régios eram personagens importantes nesse processo de comunicação que cotidianamente delineava a nova sociabilidade da Corte. Escolhidos a dedo entre os membros da elite, foram nomeados 13 homens da órbita seleta da família real. Entre os anos de 1808 e 1819, sete exerciam o sacerdócio, quase todos tendo alcançado posição de destaque. Quanto aos leigos, todos eram formados pela Universidade de Coimbra. Dentre eles, um era membro dos Reais Exércitos; dois eram médicos; e três, advogados. Posteriormente, alcançaram títulos de nobreza ou, pelo menos, mercês de ordens militares (Silva, 1994: 158). Na dinâmica da vida social, ao ocuparem cargos públicos cuja função era, antes de tudo, fiscalizar o bom andamento da "ordem", esses leais servidores da monarquia conquistavam status e prestígio, valores que dignificavam os indivíduos em uma sociedade de corte concebida pela ótica do Estado absolutista, na qual todos eram naturalmente desiguais perante a lei. As obras de responsabilidade desses homens eram encaminhadas para a Mesa do Desembargo do Paço - organismo censor no Brasil responsável por expedir todas as licenças de circulação/proibição das obras literárias que chegavam à alfândega -, a fim de que eles analisassem o conteúdo considerado pertinente ou não à leitura em sociedade.

Essa atividade, contudo, era altamente complexa. A liberação de uma obra nem sempre transcorria de forma cristalina, sendo a "ausência de procedimentos isentos e de normas claras, tanto dos que exerciam a censura, quanto dos interessados na liberação das listas" um fator intrínseco à prática da censura (Algranti, 2004: 140). Os censores tinham em suas mãos uma enorme gama de títulos e autores, o que tornava praticamente impossível o conhecimento do conteúdo de todas as obras. Nesse sentido, esses homens ilustrados exerciam a censura baseados mais em seus saberes particulares e em consonância com os valores políticos e religiosos da época do que em critérios previamente definidos. "Assim, a falta de critérios claros, a dificuldade de acesso aos róis de livros proibidos e as listas mal elaboradas desencadeavam não apenas dúvidas, mas também desavenças e disputas entre os homens de confiança do monarca", elucida Leila Algranti (2004: 144).

Com o advento da tipografia na Colônia, portanto, há uma crescente variedade de gêneros e títulos, inclusive com um aumento significativo do interesse dos leitores pelas ideias dos filósofos iluministas, como Voltaire, Rousseau e Montesquieu. Apesar da curiosidade, as obras mais famosas eram consideradas "sediciosas" pelos censores de dom João que vedavam constantemente a sua circulação. "O Sistema da Natureza, de Holbach, best seller entre as obras proibidas na França nessa época, parece também 
ter sido desejado pelos leitores da Colônia, pois os livreiros estrangeiros e portugueses tentavam introduzi-lo com frequência no país" (Algranti, 2004: 149). Inserido nesse complexo movimento, há o florescimento do romance como gênero literário, fato que contribuiu tanto para a mudança de sensibilidade dos leitores como para uma estruturação do mercado editorial no Brasil, nas primeiras décadas do século XIX.

Se, por um lado, os censores tinham especial atenção na entrada dos livros proibidos, a exemplo das obras francesas, com destaque para Émile, de Rousseau, Historie philosophique, do abade Raynal e Os direitos do Cidadão, de Mably, por outro também escolhiam e incentivavam a produção de livros muito procurados ou populares à época, como os 23 volumes de $A$ sagrada Bíblia, traduzida em português pelo padre Antonio Pereira, ao preço de 28 mil réis, vendida na loja de Paulo Martin Filho (Gazeta do Rio de Janeiro, $1810, \mathrm{~N}^{\circ} 71$ ), a nova edição em prosa da Carta de Heloísa á Abelardo; vendida por 320 réis nas lojas de Manoel Joaquim da Silva Porto e na Gazeta (Gazeta do Rio de Janeiro, 1812, N 97 ) e também o Índice da $1^{\mathrm{a}}$ parte das Preleções Filosóficas, de Silvestre Pinheiro Ferreira, dispostas em ordem alfabética, vendido nas lojas de livros de Francisco Luis Saturnino, onde podiam ser facilmente comprados nas casas livreiras da cidade (Gazeta do Rio de Janeiro, 1818, $\mathrm{N}^{\circ} 65$ ).

Com o passar do tempo, o anúncio das obras que saíam a público na cidade se tornou parte da política editorial dos diretores da Gazeta do Rio de Janeiro, que os inseriam na seção denominada Avisos. Da mesma forma que os editores utilizavam esse espaço para divulgar os livros produzidos pela tipografia real, também a sociedade fez desse espaço um locus ativo de interação social. Ao anunciarem seus interesses particulares na Gazeta do Rio de Janeiro a partir de narrações ou relatos do cotidiano, as pessoas transmitiam suas impressões coletivas no jornal de modo a conquistarem suas vozes que, pouco a pouco, tornavam-se públicas.

Desde 1809, a educação foi um tema de destaque na sociedade joanina: na seção de Avisos da Gazeta, muitas pessoas ofereciam seus préstimos educacionais. Das aulas particulares de alfabetização ao conhecimento da gramática das línguas portuguesa, francesa, inglesa, latina, perpassando a fundação de colégios exclusivos para moços ou meninas, vemos o quanto a preocupação com o enriquecimento cultural se tornava presente no cotidiano dessa sociedade, agora imersa nas mudanças culturais ocorridas na Corte.

Em 1811, o professor de primeiras letras Jordão Reinaldo, chegado como sua família de Lisboa, convidava as pessoas a fazer parte de suas aulas que, segundo ele, ensinariam "tudo o que é preciso para ser um bom hábil negociante e um útil cidadão". As aulas aconteceriam na rua dos pescadores, na casa do coronel Manoel Caetano Pinto (Gazeta do Rio de Janeiro, 1811, 
$\mathrm{N}^{\circ}$ 62). Ainda em 1811, um senhor de nome Lírio fundava um colégio de educação pública, no Catete, "onde solidamente se ensinam todas (sic) as ciências com o método mais fácil [e] novo". O local propunha-se a ensinar em pouco tempo as "melhores conveniências para a instrução de qualquer menino bem nascido", que teria a sua disposição um extenso plano acerca da solidez da casa, sob a direção de um reitor (Gazeta do Rio de Janeiro, $1816, \mathrm{~N}^{\circ} 89$ ).

A prática da escrita e leitura também fez parte dos interesses da população. Escrever com maior agilidade por meio do aprendizado da "Stenographia Portuguesa (sic), ou arte de escrever com a rapidez da palavra", foi um serviço que certamente despertou interesse de muita gente. Segundo o professor, tal prática era uma convenção adotada em todos os idiomas e que poderia trazer muitas vantagens para a interiorização da língua e gramática (Gazeta do Rio de Janeiro, 1817, $\mathrm{N}^{\circ} 50$ ). Outro aviso inusitado foi a venda de uma livraria especializada em obras jurídicas, consideradas pelo anunciante próprias e muito úteis para qualquer advogado ou magistrado (Gazeta do Rio de Janeiro, 1809, N 99).

Os constantes anúncios literários e as vendas de livros, folhetos e impressos publicados na Gazeta do Rio de Janeiro nos revelam as possíveis preferências do público leitor/consumidor da época que estava em consonância com a tradição literária herdada desde finais do século XVIII, como as belas letras, teologia, ciências e arte, história e jurisprudência.

O enraizamento do hábito da leitura, assim como as novas formas de educação nascentes, seja em âmbito público ou privado, marcam o significativo processo de transição cultural pela qual passava a sociedade joanina no início do Oitocentos. Nessa passagem, pode-se verificar o hibridismo nas formas de leitura que mesclavam as características predominantes no Antigo Regime - como as exposições de cartazes impressos ou manuscritos nas ruas e as leituras coletivas feitas geralmente em voz alta - e a formação de um novo espaço público, cujo centro será a imprensa compreendida como uma arena de debates já intimamente associada a uma prática de leitura individual feita em ambientes privados. Essa mudança é tão expressiva que, ao final do período joanino, a sociedade já manifestava suas potencialidades de leitura crítica da realidade também na esfera política.

\section{INSTITUIÇÕES REAIS E SOCIABILIDADE NA COLÔNIA}

A força dessas transformações estava vinculada também à reestruturação do espaço público imposto pela monarquia portuguesa por meio da criação de estabelecimentos régios de caráter eminentemente político e cultural. Em 
1808, foram criados o Jardim Botânico, a Academia Real da Marinha e a Impressão Régia, juntamente com os demais setores político-administrativos importantes referentes à atuação do Estado, como a polícia, a justiça, a fazenda e a área militar (Schwarcz, 2002: 247). A Casa de Suplicação, o Desembargo do Paço e a Mesa de Consciência e Ordens também foram instituições judiciais que se sobrepuseram à antiga estrutura colonial, atos que marcavam a centralidade do Rio de Janeiro como a nova capital do Império Português.

A criação do Jardim de Aclimatação (futuro Jardim Botânico), em 13 de junho de 1808 , foi um momento sui generis na constituição de um espaço público voltado para o cultivo das ciências naturais. Destinado ao cultivo de plantas exóticas, esse jardim ficou sob a responsabilidade de João Gomes da Silveira Mendonça. A partir de então foram feitos estudos para determinar as propriedades úteis das numerosas plantas que adentravam ao território. O intuito era a aplicação prática desses novos cultivos, culturas e plantações que criaram raízes na cultura brasileira pela iniciativa do Príncipe Regente. Com o interesse de multiplicar o alcance do comércio pela fabricação de substâncias úteis, introduziu-se no Rio árvores de especiarias como canela, cravo, pimenta, noz-moscada, além do plantio de chá que, vindo diretamente da China, teve cuidados especiais do monarca.

Em 13 de julho de 1811, o redator da Corte fazia um comentário muito curioso na seção Rio de Janeiro, a parte opinativa da folha. O tema contemplado foi a chegada de plantas exóticas e medicinais no Brasil, vindas da cidade de Caiena, na Guiana Francesa. Dizia o escrito que as novas plantas podiam ser cultivadas pelos lavradores que se interessassem em plantar novos gêneros, considerados muito úteis para o aumento das riquezas do Brasil. O curioso dessa passagem é que o redator não perdeu a oportunidade para utilizar o espaço com o intuito de "informar" os leitores do periódico sobre a situação política da região de Caiena, que já não mais estava sob as rédeas do "monstro" Bonaparte, assim como exaltava as atitudes "paternais" de D. João. 
Rio de Zanelio 83 de Z̈rlbo.

Com muito prazer fazernos corhecer ao Público, que pela Escuna que veio ie Cayenna, denominada Princeza D. Maria Teres $a$, , remettea o Intendente Geral daquella Coloniz, o Desemb.r jador Fo.io Severiano Maciel da Cos:a; segundo as Re.tes Ordens que havia recebido, muicas plantas de especiarias, quaes o Giroflier, ou cravo da India, e o Muscadicr, ou Noz Muscada, com muitas outras pinntas exoticas, medicinaus, e de uso, quaes a $\mathrm{Ja}$ lapa, e Arvore do Păo, a Barbedine, \&cc., pa$\mathrm{ra}$ se introduzirem no Brazil , havendo já ficado muitas das mesmas plantas em Pernambuco, onde tocuu a Escuna, e chryado aqui as outras que trouxe hum habi cuitivador de Cayenna, $M$. Germain, e que por Ordem de S. A.R. váo ser plantadas no Jardim da Lagaa de Freitas para serem dali distribuidas pelos Lavradores, que quizerem cultivar táo interessantes plantas. Estas uteis culturas, que muito podem augmientar as producçóes, e a riqueza do Brazil, sáo novos beneficios que este Imperio recebe das benignas, luminosas, e pias Mảos do seu Suberano, que náo descança hum só momento de proniovèr a felicidade dos seus Povos, e que deixara impresso no coraçáo de todos elles hum momento eterno da sua beneticencia, ja que nảo ha dia que náo seja assignalario por novos bens, procurados a favôr cos seuś Vassallos, e de quem a posteridade dirá, como de outro Tito, que viveo para numerar os seus dias pelos das graças com que felicitou os seus Povos; do que o Brazil he o mais evidente testemunho; pois no breve espaço de poucos annos, vê lançados os mais solidos fundamentos da sua futura felicidade.

Por esta occasiấo se recebècio noticias seguras de que Cayenna florecia debaixo do paternal foverno de S. A. R., e se lembrava com gosto que jả náa pertencia ao monstro Bonaparte, usurpador do Throno Francez, e que ranto opprime os que rege cont inandita tyrannia. O habil, zeloso, e fiel Intenden: te Geral tem completamente desempenhado as paternaes, e luminosas Ordens de que S. A. R. foi sero vido encarrega-lo, e se tem feito bem merecedor das graças que S. A. R. náo céssa de derramar sobre os seus fiéis servidores.

Con?

(Gazeta do Rio de Janeiro, 13 de julho de 1811, N. 56)

Entre 1808 e 1815, os anos das guerras napoleônicas, a Coroa praticou uma política baseada em um rígido controle sobre a entrada de estrangeiros, sobretudo de origem francesa e espanhola. Diante dessa conjuntura, a atenção 
e atuação dos censores estavam voltadas para proibir a circulação de obras de origem francesa, consideradas "sediciosas", razão que muito estimulou a Imprensa Régia a publicar numerosos livros, folhetos e panfletos políticos de caráter antinapoleônico, como o Manifesto da razão contra as usurpações francesas, publicado em 1809, Memórias em que se examina qual seria o Estado de Portugal se por desgraça os franceses o chegassem a dominar, A verdadeira vida de Bonaparte, ambos de 1810.

Além disso, os diretores da Gazeta praticaram um nítido processo de edição das notícias francesas, cuja linha editorial não só exaltava a figura de Napoleão como o Anticristo, como também ressaltava publicamente as desconfianças das informações editadas em periódicos franceses, como aconteceu em dezembro de 1813, ainda em meio aos conturbados ventos da guerra peninsular. Ao anunciar as notícias da guerra pela ótica francesa, o redator comentava com seus leitores:

(...) daremos alguns extratos dos jornais de França bem próprios para mais e mais nos convencermos do pouco, ou nenhum crédito que merecem as notícias que nos vem por tão má parte. Como é possível faltar a verdade com tanto descaramento? Persuadir-se-ão por ventura aqueles noveleiros, que ainda podem atormentar a Europa com fantásticos e pomposos contos? Felizmente para ela, já lá vai o lamentável tempo de prestígios! (Gazeta do Rio de Janeiro, 1813, N. 98)

Já a partir de 1815, com o fim do apogeu napoleônico, Portugal e França reatavam as relações comercias. Há então uma visível mudança de enfoque em relação tanto às notícias de origem francesa veiculadas na folha oficial quanto à política cultural da Coroa no universo luso-brasileiro (Meirelles, 2008: 130-132). A vinda da Missão Francesa para o Brasil, por exemplo, representava os aspectos "louváveis ou desejáveis" dos valores que a civilização francesa representava de positivo nas relações entre os povos europeus. Pouco depois da chegada da Missão Artística, em meados de 1816, o governo criou a Escola Real de Ciências, Artes e Ofícios, um projeto que, apesar de não ter se consolidado, estava em consonância com a nova política cultural da Coroa. ${ }^{4}$ Dois anos depois, em 1818, era fundado o Museu Real que, sob a direção do Frei José Batista da Costa Azevedo, franciscano e professor de botânica e zoologia da Academia Real Militar, tinha como objetivo estimular os estudos de botânica e zoologia no local. Mesmo não possuindo um rico acervo, dom João in persona doou uma coleção particular "composta de

4 Atualmente há uma discussão importante na historiografia se realmente houve um projeto cultural acerca da vinda da Missão Francesa para o Brasil. Maiores informações ver Schwarcz (2008). 
peças de arte, gravuras, objetos de mineralogia, artefatos indígenas, animais empalhados e produtos naturais" (Schwarcz, 2002: 256-257). O Museu também foi concebido como um local onde a memória da nobreza portuguesa se perpetuaria ao longo das gerações (Malerba, 2000: 165).

Quanto ao cuidado das finanças, a preocupação também foi visível. A fundação do Banco do Brasil, em 1808, sinalizava o nascimento de novos tempos: a força de um banco nacional dava à Colônia um novo status político e econômico não só dentro dos limites imperais da monarquia portuguesa, mas também diante dos comerciantes internacionais, especialmente europeus e norte-americanos. Desde o alvará de 28 de janeiro de 1808 , que decretava a abertura dos portos às nações amigas, o Brasil vivenciava na prática uma nova realidade: a decisão rompia definitivamente com o Pacto Colonial ou Exclusivismo Metropolitano, já que a lei permitia a importação de gêneros e mercadorias estrangeiros, sobretudo das potências que mantinham boas relações com a Coroa Portuguesa, notadamente a Inglaterra.

\section{Criação do Banco do Brasil.}

\section{Alvará do Príncipe Dom João (12 out. 1808)}

Eu, o Príncipe Regente,

Faço saber aos que este meu Alvará com força de lei virem que, atendendo a não permitirem as atuais circunstâncias do Estado, que o meu Real Erário possa realizar os fundos de que depende a manutenção da Monarquia, e o bem comum dos meus fiéis vassalos, sem as delongas que as diferentes partes, em que se acham, fazem necessárias para a sua efetiva entrada: a que os bilhetes dos direitos das Alfândegas tendo certos prazos nos seus pagamentos, ainda que sejam de um crédito estabelecido, não são próprios para o pagamento de soldos, ordenados, juros e pensões, que constituem os alimentos do corpo político do Estado, os quais devem ser pagos nos seus vencimentos em moeda corrente; e a que os obstáculos, que a falta de giro dos signos representativos dos valores põem ao comércio, devem quanto antes ser removidos, animando e promovendo as transações mercantis dos negociantes desta e das mais praças dos meus domínios, e senhorio, com as estrangeiras: sou servido ordenar que nesta Capital se estabeleça um banco público que, na forma dos estatutos que com este baixam, assinados por Dom Fernando José, de Portugal, do meu Conselho de Estado, Ministro Assistente ao Despacho do Gabinete, Presidente do Real Erário e Secretário de Estado dos Negócios do Brasil, ponham em ação os cômputos estagnados assim em gêneros comerciais, como em espécies cunhadas; promova a indústria nacional pelo giro e combinação dos capitais 
isolados, e facilite juntamente os meios e os recursos de que as minhas rendas reais e as públicas necessitarem para ocorrer as despesas do Estado.

E querendo auxiliar um estabelecimento tão útil e necessário ao bem comum e particular dos povos, que o Onipotente confiou ao meu zelo e paternal cuidado: determino que os saques dos fundos do meu Real Erário, e as vendas dos gêneros privativos dos contratos, e administrações da minha real fazenda, como são os diamantes, pau Brasil, o marfim e urzela (sic), se façam pela intervenção do referido Banco Nacional, vencendo sobre o seu líquido produto a comissão de dois por cento, além do prêmio do rebate dos escritos da Alfândega que em virtude do meu real Decreto de 5 de setembro do corrente ano fui servido mandar praticar pelo Erário Régio, para ocorrer ao efetivo pagamento das despesas de trato sucessivo da minha Coroa, que devem ser feitas com espécies metálicas.

$\mathrm{E}$ atendendo à utilidade, que provém ao Estado, e ao comércio do manejo seguro dos cabedais e fundos do referido Banco; ordeno que, logo que ele principiar as suas operações, se haja por extinto o cofre de depósito que havia nesta cidade a cargo da Câmara dela, e determino que no sobredito Banco se faça todo e qualquer depósito judicial ou extrajudicial de prata, ouro, jóias e dinheiro; e que o competente conhecimento de Receita passado pelo Secretário da Junta do Banco, e assinado pelo Administrador da competente Caixa, tenha em juízo e fora dele todo o valor e crédito de efetivo e real depósito, para se seguirem os termos que por minhas leis se não devem praticar sem aquela cláusula, solenidade ou certeza; recebendo o sobredito Banco o mesmo prêmio que no referido Depósito da Cidade se descontava às partes. E outrossim sou servido mandar que os empréstimos a juros da lei, que pelo Cofre dos órfãos e Administrações de Ordens Terceiras, e Irmandades se faziam até agora a pessoas particulares da publicação deste Alvará, agora em diante se façam unicamente ao referido Banco, que deverá pagar à vista nos prazos convencionados os capitais, e nas épocas costumadas os juros competentes, debaixo da hipoteca dos fundos da sua caixa de reserva; distratando (sic) desde logo aqueles cofres as somas que tiverem em mãos particulares ao referido juro para entrarem imediatamente com elas no sobredito Banco Público debaixo das mesmas condições.

Em todos os pagamentos, que se fizerem à minha Real Fazenda, ser o contemplado, e recebidos como dinheiro os bilhetes do dito Banco Público pagáveis ao portador ou mostrador à vista; e da mesma forma se distribuirão pelo Erário Régio nos pagamentos das Despesas do Estado. 
E este se cumprirá como nele se contém. Pelo que mando à Mesa do Desembargo do Paço, e da Consciência e Ordens, o Presidente do meu Real Erário e Conselho de Fazenda; Regedor da Casa da Suplicação do Brasil, Governador da Relação da Bahia, Governadores e Capitães-Generais e mais Governadores do Brasil e dos meus domínios ultramarinos, e a todos os Ministros de Justiça e mais pessoas a quem pertencer o conhecimento e execução deste Alvará, que o cumpram e guardem, e façam inteiramente cumprir e guardar como nele se contém, não obstante quaisquer leis, alvarás, regimentos, decretos ou ordens em contrário, porque todos e todas hei por derrogados para este efeito somente, como se deles fizesse expresso e individual menção; ficando aliás sempre em seu vigor. E este valerá como carta passada pela Chancelaria, ainda que por ela não há de passar, e que o seu efeito haja de durar mais de um ano, sem embargo da ordenação em contrário; registrando-se em todos os lugares, onde se costumam registrar semelhantes Alvarás.

Dado no Palácio do Rio de Janeiro, 12 de outubro de 1808.

Príncipe

D. Fernando José, de Portugal

Alvará com força de lei, pelo qual Vossa Alteza Real há por bem criar um Banco Nacional nesta Capital, para animar o comércio; promovendo os interesses reais e públicos, na forma que nele se declara.

Para Vossa Alteza Real ver.

João Álvares de Miranda Varejão o fez.

Registrado nesta Secretaria de Estado dos Negócios do Brasil no Livro 1, de Decretos, Leis, Alvarás e Cartas Régias sobre Fazenda a fol. 28. Rio de Janeiro, 14 de outubro de 1808 .

Em 1810, foi criada a câmara de registros das Mercês e a Corporação de Armas, dois espaços que organizavam eficazmente o nascimento de uma classe nobre deste lado do Atlântico. "A concessão de graças honoríficas, como os títulos e os lugares das ordens militares e religiosas foi fartamente utilizada pelos monarcas como capital simbólico fundamental para retribuir a fidelidade de seus vassalos", explica o historiador Jurandir Malerba (2000: 212).

Os laços que aproximavam os súditos do Rei também eram cotidianamente reforçados durante o Beija-mão. $\mathrm{O}$ ato de beijar a mão do monarca era repleto de significados políticos intrinsecamente associados à lógica do Antigo Regime Português. Todos os dias, por volta das oito horas 
da noite (exceto aos domingos e feriados), dom João recebia seus súditos em uma sala especial no palácio de São Cristóvão, sua residência oficial.

O palácio de São Cristóvão, da Quinta da Boa Vista, foi uma doação de Elias Antonio Lopes, um dos mais ricos negociantes do Rio. A alta consideração desse vassalo para com a monarquia foi recompensada por dom João, que gratificou a sua generosa oferta com a sua nomeação como comendador da Ordem de Cristo, Fidalgo da casa real e administrador da mesma Quinta. ${ }^{5}$ As "subscrições voluntárias" dos vassalos portugueses e fluminenses também foram uma forma muito eficaz do Estado português arrecadar grandes fortunas para a sustentação dos cofres públicos. Geralmente, a generosidade desses súditos fiéis da Coroa tinha uma meta muito bem traçada: conquistar as graças de dom João, um status muito caro a uma sociedade de corte cujos valores como honra e prestígio eram fundamentais. A cada doação, a visibilidade pública desses ricos negociantes - seja através da publicação de seus nomes nos folhetos da secretaria dos negócios do Reino, seja pelas páginas da Gazeta do Rio de Janeiro - era colocada diante da possibilidade da conquista de novas mercês.

Durante o beija-mão, os trajes e as nobres qualidades eram essenciais. Quem optasse por cumprir esse ritual tinha plena consciência de que vivia em uma sociedade de corte rigidamente marcada por uma hierarquia dos lugares sociais. Aqueles que não tivessem casta de fidalguia aguardariam na segunda sala enquanto os nobres vassalos beijavam as mãos do monarca na sala principal, onde estavam presentes titulares e ministros reais. Tal era a importância desse ritual para a sociedade de corte que duas vezes por semana o ministro Tomás Antonio Vilanova Portugal recebia os pedidos das mercês.

5 BNRJ. Relação das festas que se fizeram no Rio de Janeiro, quando o príncipe Regente N.S e toda a sua família chegarão pela primeira vez áquella capital. Ajuntando-se algumas particularidades igualmemte curiosas, e que dizem respeito ao mesmo objeto. Lisboa, Impressão Régia, 1810, p.10. Seção de Obras Raras, [36,0,21]. 
N. ${ }^{0}$ I I.

\section{GAZETA Do RIO DE JANEIRO.}

QUARTA FEIRA I9 DE OUTUBRO.

Dwirina . . vim premevet iasitam,

Rectigae cultas pectora reberant.

HORAT.

T OS É Antoninuajāo da sobscrips̆ăo dos Commerciantes.

- Francisco José das Neves.

Manoel Ignacio de Souza Araujo.

$6 \mathrm{~d} 400$

Joáo Antonio de Castro Palma.

Francisco Joaquim de Lima.

José Pereira da Silva Guimaráes.

Manoel Joaquim de Azevedo.

Manuel de Moura Guimaries

Nicoláo Joaquim Perétá da Silva.

Joáo António de Fteitas. -

Rudrigo Jose Lopes. "-

Françisco" Jósé d' Almeida Lima.

Antonio de Söıza Pinto.

Antonio Pinheiro Guimaráes.

Continuar-se-ba.

120800

$4 \otimes \infty \infty$

$4 \$ 000$

60400

6 d 4 co

$4 \$ 000$

$8 d 000$

60400

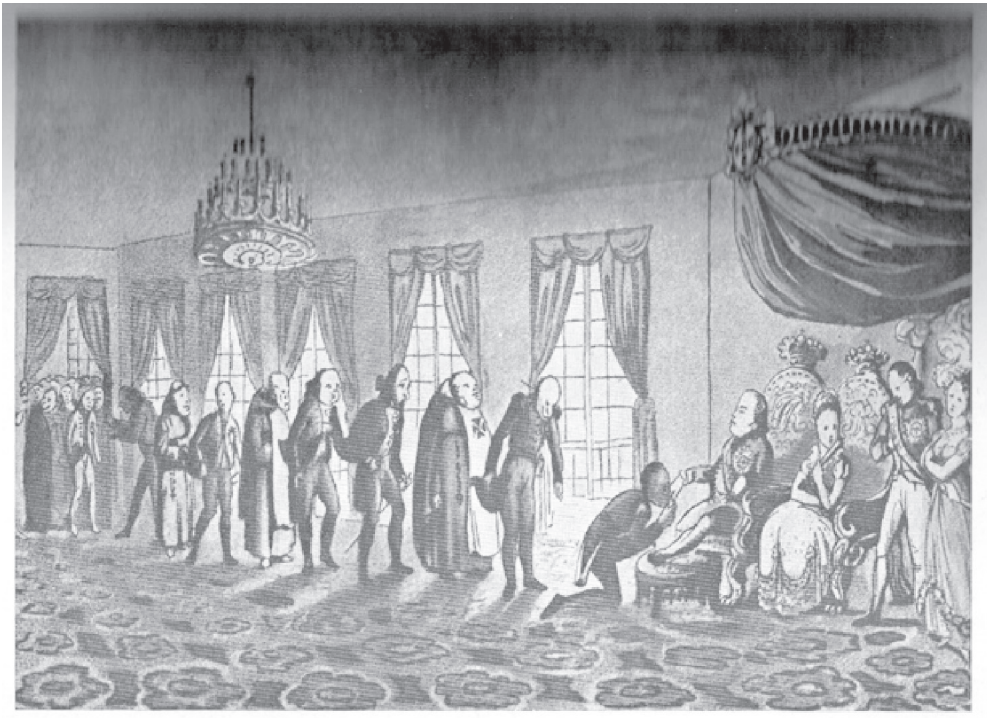


Logo nas primeiras edições da Gazeta, em 1808, era publicada a subscrição e os valores doados pelos vassalos da Coroa em prol do socorro dos súditos portugueses que ficaram no Reino à sorte dos franceses. Esses mesmos vassalos eram aqueles que cortejavam dom João cotidianamente à espera de benesses e também aqueles que patrocinavam os projetos culturais da monarquia nesse lado do Atlântico.

O caso da construção do Teatro de São João é emblemático. Os comerciantes de grosso trato do Rio se mobilizaram a fim de angariar fundos para que a capital do Império tivesse uma casa de espetáculos à sua altura. Para o sucesso do empreendimento, criaram um sistema de loteria - uma contribuição fundamental dos vassalos de dom João para a construção e sucesso do espaço - que ficava sob a responsabilidade de Fernando Carneiro Leão, proeminente negociante que neste caso respondia pelas contas e pelos prêmios.

Continua; äo da Relaçäo das Pessoas, que tem concorrilo para soccorro- dos Vassallos de S. A. R. residentes em Portagal desde 20 de Outubro ate 7 de Novembro.

O Capitáa Francisco José Ignacio da Silva.

O Reverendo Antonio José Escudeiro Ferreira de Souza. Em papel Moeda.

$16 \$ 200$

José Pinco de Miranda.

O Brigadeiro Domingos de Azevedo Coutinho Mello Soares Xinxorro.

O Coronel Joaquim Vicente dos Reis.

Fstacio Gularte Pereira.

Felisberto José de Almeida.

Antonio Pedro Teixeira.
Torcato Soares Loureiro, Official da Secretaria da Meza do Dezem-

bargo do Paço.
Hum Espadim de ouro de filagrana, offerecido por hum Patriota pa-
ra ser dado á pessoa que mais se distinguir na Restautaçáo de Lisboa.

Continuar-se-ba.

(Gazeta do Rio de Janeiro, 23 de novembro de 1808, n.21)

O Teatro São João, inaugurado em 1813, substituía a Casa de Ópera da cidade e foi um empreendimento amplamente noticiado na Gazeta do Rio de Janeiro, que informava sobre as datas do pagamento das loterias. Sob a direção do músico e mestre de empresas teatrais Bernardo José de Sousa e Queiroz, a peça O juramento do numes - de autoria de Gastão Fausto da Camara Coutinho - inaugurava as atividades que ocorreriam a partir de então no teatro. A peça exaltava a bravura do povo português, ainda imerso nas complexas consequências das guerras napoleônicas. A cena final retratava o tempo de heroísmo desse povo que jurava fidelidade ao Príncipe, cujo retrato aparecia ao fundo do palco. 
Perante a vossa Efígie augusta e sacra

Vasto Soberano de Nações diversas,

Cujo braço ostentoso alcança, e rege

Os hemisférios dois com as rédeas fulvas;

Perante a vossa Efígie e sobre as aras

Onde o eterno fulgor as nuvens doura

Juramos pelo escuro Estigio lago,

Nós, do grão Rei dos Reis, família e sangue

Que os Povos de Ulisses esclarecidos

Inquietados serão, mas não vencidos.

(apud Malerba, 2000: 112).

A partir de 1813, portanto, o gosto do Príncipe Regente pelas representações cênicas foi sendo popularizado e, aos poucos, tornou-se acessível a muita gente: peças teatrais, concertos musicais e uma ampla gama de produções artísticas encenadas por artistas europeus acabavam por englobar a sociedade fluminense, agora em estreito contato com valores "civilizados". Como bem observou Jurandir Malerba, havia uma continuidade entre o palco, o púlpito, a rua e o palácio real, uma vez que os mesmos símbolos circulavam por toda a cidade (Malerba, 2000: 93).

Obviamente que o Teatro São João foi um espaço concebido para o divertimento das classes abastadas intelectual e financeiramente: por lá convergiam homens e mulheres da nobreza portuguesa, assim como os ricos comerciantes cariocas e suas famílias. Aos escravos e aos homens livres pobres, o ingresso à nova arena de encenações no campo da arte $\mathrm{e}$ da política ainda era um sonho a ser conquistado. Porém, a despeito das etiquetas e hierarquias da corte, intrínsecas ao Antigo Regime, o fato é que o teatro já nascia como um ponto de reunião mundana que permitia a crítica dos costumes pela evocação de múltiplas vozes.

A consolidação desse espaço foi tão forte que a partir de 1821, sobretudo durante o processo de Independência, já era nítida a teatralização da política nos palcos. "Sem ser lugar de deliberação das autoridades, nem ponto predefinido para encontros políticos, a sala de espetáculos foi tornandose um canal da expressão de diferentes vontades coletivas. Muitas vezes indiferentes à peça teatral representada, os espectadores podiam chamar mais atenção do que os atores no palco", esclarece-nos o historiador Marco Morel (2005: 233).

Ainda em 1813, foi criada a Escola Cirúrgica e, no ano seguinte, era aberta ao público a Real Biblioteca. Ao institucionalizar o acesso à leitura e a um amplo universo cultural vigente no Velho Mundo, também a biblioteca inaugurava novos hábitos e práticas culturais. Mapas, canetas de pena, 
tinteiros, estantes recheadas de livros, papelarias passavam a fazer parte do cotidiano das pessoas. $\mathrm{O}$ conhecimento de um novo universo ao alcance das mãos trazia consigo a possibilidade das ideias de sedição no campo da política. O raiar desse espaço público fazia agora parte de um mundo que transcendia o rigor que a proibição das leis e a atuação dos censores poderiam prever.

Nesse cenário, Silvestre Pinheiro Ferreira redigiu um compêndio publicado entre 1813 e 1820 . Sob o título de Preleções Philosophicas, os escritos do Ferreira (um dos principais conselheiros de dom João no Brasil, além de diretor da Gazeta do Rio de Janeiro e ministro régio) difundiam a importância dada à retórica, concebida como um instrumento cotidiano de argumentação e convencimento. Os interessados em estudar as Preleções tinham a oportunidade de cursar as aulas de Ferreira, ministradas no Real Colégio São Joaquim. O início e conteúdo das aulas foram difundidos na seção de avisos da Gazeta.

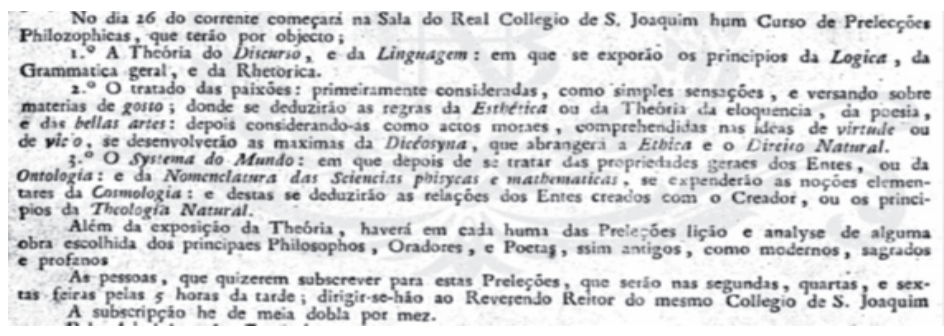

(Gazeta do Rio de Janeiro, 14 de Abril de 1813, n. 30)

As Preleções evidenciam um importante avanço no enraizamento da cultura erudita no Brasil, não só pelo fato de disseminar um conhecimento mais teórico acerca de novas possibilidades de estrutura de pensamento filosófico, mas justamente porque foi produzida por um dos pensadores portuguêses de maior destaque do século XIX, segundo a ótica do escritor e historiador português Alexandre Herculano (1938: 176-177).

Além dessas instituições de grande importância científica e cultural, vemos ainda o florescimento de outras iniciativas reais que muito contribuíram para o debate de ideias no espaço público no período. Manuel Ferreira de Araújo Guimarães, homem de letras de grande expressão do Império Português, lançava, em 1813, o primeiro jornal literário, O Patriota, que circulou até fins de 1814. Os artigos de caráter científico e literário, publicados no jornal, tinham como intuito formar os leitores de uma maneira geral, além de serem direcionados especificamente para agricultores, homens de ciência e escritores. 
Os subscritores e leitores do jornal eram pessoas ilustríssimas da Corte. Se da realeza contam entre os assinantes a princesa Carlota Joaquina e a Infanta d. Maria Isabel, da nobreza pululavam os nomes de grande destaque nos círculos da órbita monárquica, como os barões de São Lourenço e do Rio Seco, os condes dos Arcos, de Bel Monte, Galvêas, os marqueses de Borbas e de Torres Novas, entre tantas outras personalidades da alta nobreza joanina. Mas como bem nos alerta o historiador Marco Morel, o que estava em jogo era a consolidação de uma camada de homens de letras. Como leitores, esses sujeitos davam um passo à frente na formação de um público privilegiado de redatores ou de escritores públicos, como se dizia na época. "Sábios", "literatos", "ilustrados”, “esclarecidos" se colocavam como agentes mesmo sem a legitimidade de se constituírem como força moral e crítica para interferirem nos negócios públicos. Nesse princípio do século XIX, tal posição era uma espécie de nostalgia da República das Letras que brilhara no século anterior, mas acenava para um plano efetivo de relações naquela sociedade" afirma Morel (2007: 32). Pelas páginas de O Patriota, esses ilustrados refletiam sobre os novos (e múltiplos) sentidos da Pátria que nascia nas duas margens do Atlântico luso-brasileiro, concebida também como um lócus de discussão e prática de novas posturas singulares inseridas sob a perspectiva do Iluminismo luso-americano, imerso no universo imperial português (Kury, 2007: 141-142). No prospecto do jornal, Araújo destacava o diálogo cultural com a Europa, a nova ordem que desejava constituir no espaço público. A produção do jornal e a cooperação da sociedade nesse projeto, afirma o editor, "nos vingar[ão] da acusação de ineptos, que nos fazem autores estrangeiros, e por desgraça alguns nacionais."

Se, por um lado, todas essas iniciativas e transformações também apareciam no comportamento político da sociedade joanina que, desde a chegada da corte, tinha um amplo universo cultural ao seu alcance; por outro, a estruturação e funcionamento dessas instituições régias estavam estreitamente vinculados a um projeto político administrativo do Império Português, cujas raízes remontam aos debates do século XVI.? Para além

\footnotetext{
6 Ferreira. BNRJ, OR/ DOC 37,5 1B.

7 Para o debate historiográfico sobre esse tema, consultar, entre outros: PONDÉ, Francisco de Paula e Azevedo, "D João VI e a emancipação intelectual do Brasil", in Revista do Instituto Histórico e Geográfico, Rio de Janeiro, tomo 279, 1968, p.114. LIMA, Oliveira, Dom João VI no Brasil, $3^{\text {a }}$ ed., Topbooks, 1996. ALEXANDRE, Valentim, Os sentidos do Império: questão nacional e questão colonial na Crise do Antigo Regime Português, Edições Afrontamento, Lisboa, 1993; LYRA, Maria de Lourdes Viana. A utopia do poderoso império: Portugal e Brasil:bastidores da política (1798-1822), Rio de Janeiro, Sete Letras, 1994. MAXWELL, Kenneth, Pombal: paradox of the enlightenment, Cambridge University Press, Cambridge, 1995. BITTENCOURT, José Neves, "Iluminando a Colônia para a Corte: o museu real e a Missão Francesa como marcos exemplares da política de
} 
desse propósito, a real transladação da monarquia no início do século XIX também desejava atingir metas culturais mais amplas sob a perspectiva de um "projeto civilizatório" que visava à ocidentalização da América Portuguesa. A tônica seria a importação de padrões civilizatórios europeus como uma tentativa de inserir essa parte do mundo no Ocidente, sendo o Rio de Janeiro transformado em um autêntico laboratório de civilização sob a perspectiva de uma Europa possível (Santos, 2000: 9-10).

administração portuguesa no Brasil", in Seminário Internacional Dom JoãoVI: um rei aclamado na América, Rio de Janeiro, Museu Histórico Nacional, 20oo, p. 114-121. 